University of Nebraska - Lincoln

DigitalCommons@University of Nebraska - Lincoln

USDA National Wildlife Research Center - Staff Publications
U.S. Department of Agriculture: Animal and Plant Health Inspection Service

February 2007

\title{
Mountain beaver home ranges, habitat use, and population dynamics in Washington
}

\author{
W. M. Arjo \\ USDA/APHIS/WS/NWRC \\ R. E. Huenefeld \\ AGEISS Environmental, Inc. \\ D. L. Nolte \\ USDA-APHIS-Wildlife Services, Dale.L.Nolte@aphis.usda.gov
}

Follow this and additional works at: https://digitalcommons.unl.edu/icwdm_usdanwrc

Part of the Environmental Sciences Commons

Arjo, W. M.; Huenefeld, R. E.; and Nolte, D. L., "Mountain beaver home ranges, habitat use, and population dynamics in Washington" (2007). USDA National Wildlife Research Center - Staff Publications. 677. https://digitalcommons.unl.edu/icwdm_usdanwrc/677

This Article is brought to you for free and open access by the U.S. Department of Agriculture: Animal and Plant Health Inspection Service at DigitalCommons@University of Nebraska - Lincoln. It has been accepted for inclusion in USDA National Wildlife Research Center - Staff Publications by an authorized administrator of DigitalCommons@University of Nebraska - Lincoln. 


\title{
Mountain beaver home ranges, habitat use, and population dynamics in Washington
}

\author{
W.M. Arjo, R.E. Huenefeld, and D.L. Nolte
}

\begin{abstract}
The mountain beaver (Aplodontia rufa (Rafinesque, 1817)), endemic to western North America, is the only extant member of the family Aplodontidae. Limited information on movements and habitat use throughout the species' range is available. We radio-collared 41 mountain beavers to determine home ranges, dispersal, habitat use, and population densities on two managed forest sites in coastal Washington. Both sites were recently harvested for timber. The Donovan site (16.6 ha) was treated with herbicide before seedling planting and the Sylvia site ( 8.9 ha) was not treated. Mountain beaver home ranges (Donovan: $4.18 \pm 0.81 \mathrm{ha}$; Sylvia: $1.39 \pm 0.4 \mathrm{ha}$ ) were greater than previously reported in the literature $(0.02-0.2 \mathrm{ha})$. Home ranges $(P=0.009)$ and core use areas $(P=0.05)$ on the herbicide-treated Donovan site were larger than those observed on the untreated Sylvia site. Mountain beaver population density declined from $2002(n=16)$ to 2003 $(n=8)$ on the Donovan site, and reinvasion onto the site after removal trapping was low $(n=7)$. Population density more than doubled on the Sylvia site from $2002(n=21)$ to $2003(n=55)$, and reinvasion was greater $(n=27)$ than observed at Donovan. In addition, we documented habitat characteristics centered at 9 Donovan and 10 Sylvia nest locations. Sites were similar in most habitat characteristics, but the Sylvia site had more herbaceous forbs, stumps, and woody debris. Our findings suggest that mountain beaver populations and home ranges are affected by availability of forage, such as herbaceous forbs, after herbicide treatment, as well as by availability of woody cover.
\end{abstract}

Résumé : Le castor de montagne (Aplodontia rufa (Rafinesque, 1817)), endémique à l'ouest de l'Amérique du Nord, est le seul représentant actuel de la famille Aplodontidae. On possède peu de renseignements sur les déplacements et l'utilisation de l'habitat de cette espèce dans son aire de répartition. Nous avons muni de colliers radio 41 castors de montagne afin de déterminer les aires vitales, la dispersion, l'utilisation de l'habitat et les densités de population dans deux sites de forêts aménagées dans la région côtière de l'état de Washington. Les deux sites ont récemment subi une coupe de bois; le site de Donovan ( 16,6 ha) a été traité à l'herbicide avant la replantation, mais non celui de Sylvia ( 8,9 ha). Les aires vitales des castors de montagne (Donovan : 4,18 $\pm 0,81$ ha; Sylvia : 1,39 $\pm 0,4$ ha) sont plus étendues que celles mentionnées antérieurement dans la littérature $(0,02-0,2$ ha). Les aires vitales $(P=0,009)$ et les noyaux d'utilisation intensive $(P=0,05)$ sont plus grands sur le site de Donovan traité à l'herbicide que sur le site non traité de Sylvia. La densité de population des castors de montagne a décliné de $2002(n=16)$ à $2003(n=8)$ sur le site de Donovan et la recolonisation du site après le retrait d'animaux par trappage est faible $(n=7)$. La densité de population a plus que doublé sur le site de Sylvia de $2002(n=21)$ à $2003(n=55)$ et le taux de recolonisation $(n=27)$ est plus élevé qu'au site de Donovan. Nous avons, de plus, déterminé les caractéristiques de l'habitat d'après l'étude de 9 sites de nidification à Donovan et 10 à Sylvia. Les sites sont semblables en ce qui a trait à la plupart des caractéristiques de l'habitat, à l'exception d'une quantité plus grande de plantes herbacées, de souches et de débris ligneux au site de Sylvia. Nos résultats indiquent que les populations et les aires vitales des castors de montagne semblent être affectées par la disponibilité du fourrage (par exemple, de plantes herbacées) après le traitement à l'herbicide, ainsi que par la disponibilité de la couverture ligneuse.

[Traduit par la Rédaction]

\section{Introduction}

The family Aplodontidae currently consists of the monotypic genus Aplodontia. Mountain beavers (Aplodontia rufa (Rafinesque, 1817)) are known by a variety of common names including boomer, whistler, and the Native American names sewellel and showt'l, and very little change in geo- graphic distribution of this archaic semi-fossorial rodent species has occurred since the late Oligocene (Carraway and Verts 1993). Seven subspecies are currently recognized (Dalquest and Scheffer 1945; Hall 1981), and the largest distribution of a single subspecies $(A, r, r u f a)$ ranges from southern British Columbia, Canada, through coastal Washington and into central Oregon. In Canada, $A$. rufa is desig-

Received 20 September 2006. Accepted 23 January 2007. Published on the NRC Research Press Web site at http://cjz.nrc.ca on 13 March 2007.

W.M. Arjo, ${ }^{1}$ R.E. Huenefeld, ${ }^{2}$ and D.L. Nolte. ${ }^{3}$ United States Department of Agriculture, Animal and Plant Health Inspection Service, Wildlife Services, National Wildlife Research Center (USDA/APHIS/WS/NWRC), Olympia Field Station, 9730-B Lathrop Industrial Drive SW, Olympia, WA 98512, USA.

${ }^{1}$ Corresponding author (e-mail: wendy.m.arjo@aphis.usda.gov).

${ }^{2}$ Present address: AGEISS Environmental, Inc., Tacoma, WA 98408, USA.

${ }^{3}$ Present address: USDA/APHIS/WS/NWRC, $4101 \mathrm{La}$ Porte Avenue, Fort Collins, CO 80521, USA. 
nated as a species of concern by the Committee on the Status of Endangered Wildlife in Canada (Government of Canada 2007).

Mountain beavers are most commonly found at lower elevations in humid, open-canopied forests with a densely vegetated understory (Feldhamer et al. 2003), although some populations in the Sierra Nevada Range are found at elevations of up to $3000 \mathrm{~m}$. In the Pacific Northwest, mountain beavers prefer open-canopy habitats often produced after timber harvesting and tend to be less numerous in closedcanopy habitats (Hooven 1977; Neal and Borrecco 1981). Sword fern (Polystichum munitum) and salal (Gaultheria shallon) are clipped year-round for food and bedding (Neal and Borrecco 1981) and are considered to be important resources for Pacific Northwest mountain beavers (Voth 1968; Allen 1969).

Only three studies have previously documented mountain beaver home ranges and movements. Home range sizes have been reported in $\geq 20$-year-old conifer forests ( 0.26 ha, on average: Lovejoy and Black 1979a) and in later seral stage Douglas-fir (Pseudotsuga menziesii) forests $(0.1$ to 0.17 ha: Neal and Borrecco 1981). Home ranges averaged 0.12 ha in a young, regenerating forest ( 8 years old) that had been seeded and intermittently hand planted in western Washington (Martin 1971). In older conifer forests, mountain beaver densities seldom exceed 4 beavers per ha (Borrecco and Anderson 1980), but after timber harvest, densities can reach 15-20 beavers per ha (Hooven 1977; Neal and Borrecco 1981). Information on mountain beaver population dynamics and movements in newly reforested areas, where populations are thought to be high, is lacking.

Our goal was to increase knowledge of mountain beaver biology and demographics in recently harvested forest areas in Washington. Specific objectives of the study were to $(i)$ estimate mountain beaver population densities, (ii) determine sizes of home ranges and areas of use for mountain beavers, (iii) determine site-specific habitat characteristics around nest locations, and (iv) determine dispersal movements.

\section{Materials and methods}

\section{Study area}

We selected two $\leq 1$-year-old timber harvest sites on managed timberlands (15 km apart) in Grays Harbor County, Washington, to document mountain beaver movements. The Donovan site (107 m elevation) was a 16.6-ha naturalregeneration Douglas-fir site surrounded mainly by established timber stands $>40$ years old. The exceptions were the northwest corner of the site, which was bordered by a 60 year-old alder plantation, and the northern corner, which was bordered by an 11-year-old Douglas-fir regeneration forest. A riparian management zone (RMZ), a buffer area around fish-bearing streams containing $\leq 40$-year-old forested habitat, bordered the southeast edge of the site.

We used the western 8.9 ha of the Sylvia site (total 15 ha) ending at a natural draw for this study site. The eastern portion of the study site was bordered by the rest of the clearcut. The northern portion of the site was bordered by an RMZ and older trees ( $30-40$ years old), and the western portion consisted of Douglas-fir regeneration forest $(10-15$ years old). To the south of the site was a 35-year-old Douglas-fir site. Unlike the relatively flat Donovan site, the Sylvia site contained two main north - south draws and two minor northsouth draws. The main draws maintained year-round water sources, whereas the minor draws were ephemeral. Prior to timber harvest, Sylvia was also a natural-regeneration Douglas-fir site.

Stand management in coastal Washington usually consists of an herbicide treatment the fall prior to seedling planting. The chemical site preparation decreases woody vegetation and herbaceous growth that can compete with newly established seedlings. After the start of the study, forest managers decided not to chemically treat the Sylvia site because of a high concentration of streams throughout the site. This management decision allowed us to examine effects of vegetation on mountain beaver movements and population densities. Donovan was aerially sprayed prior to planting in August 2001 with a mixture of 48 ounces of Accord Concentrate (Dow AgroSciences) and 8 ounces of Activator 90 (a surfactant) using a 98 Whiskey helicopter. Seasonal swamps occurred on the southern end of Donovan and in a small section in the middle of the site; otherwise no permanent water source existed on the site outside of the RMZ. Both sites were planted in March 2003 with red alder (Alnus rubra) at 275 trees per ha.

\section{Trapping and monitoring}

We livetrapped mountain beavers in Tomahawk traps $(15 \mathrm{~cm} \times 15 \mathrm{~cm} \times 60 \mathrm{~cm}$; Tomahawk Live Trap Company, Tomahawk, Wisconsin) placed in active runways. We enlarged the runways to accommodate the doubleended traps and then traps were baited with half an apple threaded on a stick over the trap pan. In addition, we suspended a small mesh bag containing 5-6 pieces of rodent blox (Animal Specialties, Hubbard, Oregon) from the top of the trap. Sword fern was placed on top of the trap and then covered with black plastic to simulate a tunnel system. Traps were checked every morning and in the late afternoon and removed after an animal within the system was captured. Animals were removed from the traps by coaxing them into burlap sacks. Animals were weighed, sexed, and ear-tagged in both ears with Monel No. 1005-1 tags (National Band and Tag Co., Newport, Kentucky) and individually marked with AVID (American Veterinary Identification Devices, Norco, California) microchips. In addition, we fitted animals weighing over $800 \mathrm{~g}$ with mortality-sensor radio transmitter collars $(\leq 20 \mathrm{~g}$; Advanced Telemetry Systems, Isanti, Minnesota). We released animals at their point of capture after $\leq 10 \mathrm{~min}$ of handling. Capture and handling protocols were approved by the Animal Care and Use Committee at the National Wildlife Research Center.

We monitored radio-collared mountain beavers to determine causes of death. The possible cause of death was determined by examining the carcass for external and internal injuries, puncture wounds, and hemorrhaging. Physical evidence near the carcass, such as tracks, scat, or hair, also assisted in determining the possible cause of death. Annual survival rates for males and females for 2002 and 2003 were extrapolated from daily survival rates using MICROMORT (Heisey and Fuller 1985). Reproductive survival 
rates (1 February - 30 June) and nonreproductive survival rates ( 1 July - 31 January) for 2002 and 2003 were calculated for males and females.

\section{Home ranges, activity, and movements}

Radio-collared animals were located $\geq 2$ times/week using a handheld 3-element directional Yagi antenna. We monitored animals throughout $24 \mathrm{~h}$ periods, with at least $2 \mathrm{~h}$ between consecutive locations. Mountain beaver activity was determined based on attenuation (fluctuation in intensity) of the animal's signal (Gaines and Lyons 2003). Animal locations were triangulated using the Locate software package (Pacer Software, Truro, Nova Scotia) with $\geq 2$ bearings taken $<10 \mathrm{~min}$ apart. To minimize triangulation error, bearings intersecting at $\leq 20^{\circ}$ or $\geq 160^{\circ}$ were censored from the analyses (Gese et al. 1988). We measured telemetry bearing error in the study areas using reference test transmitters (White and Garrott 1990). Test transmitters were placed at unknown locations on the study sites and two observers triangulated on each transmitter $\geq 50$ times from two locations. The same observers monitored mountain beavers on both study sites. Home range and core use areas were determined using the adaptive kernel method in the home range program CALHOME (J. Kie, Pacific Southwest Forestry and Range Experimental Station, Fresno, California). We used the 95th percentile maximum probability contour to delineate home ranges and two-thirds of the maximum probability (62\%) to distinguish core use areas (Shivik et al. 1996). We compared overall home range and core area sizes (locations of an individual throughout the entire study period) and seasonal ranges (reproductive and nonreproductive) and core areas between the two study sites and between sexes using an ANOVA (PROC GLM, SAS ${ }^{\mathrm{P}}$ Version 8.0, SAS Institute Inc., Cary, North Carolina).

\section{Habitat identification}

Mountain beavers are highly dependent upon underground nest (or den) chambers, which fulfill both reproductive and nonreproductive functions. Belowground nest sites were located by homing in on each mountain beaver at least once a month during the day. Nest sites were flagged and marked with the date of the location. We determined each mountain beaver's nest site after amassing $\geq 6$ locations within a $1 \mathrm{~m}^{2}$ area. We used these belowground nest site locations to subsample the habitat within each mountain beaver's home range, assuming that nests were the center of activity within each range (each nest fell within the 62nd percentile area of utilization). A 0.1 -ha circular plot (17.9 m radius) centered above each nest was used to identify nest-site habitat. Within this plot we measured numbers of active and inactive burrows, number of stumps, number of uprooted stumps, distance to water, slope, and downed woody vegetation. Downed woody vegetation was classified into three categories based on decay, following Hacker and Coblentz (1993): (1) $<5 \%$ bark cover, (2) 5\%-95\% bark cover, and (3) $>95 \%$ bark cover. We measured soil resistance with a penitrometer at the nest and $2 \mathrm{~m}$ upslope and downslope from the nest, and we extracted three soil samples from these areas to measure water content. Soil samples were weighed, placed in aluminum pans in an oven at $105^{\circ} \mathrm{C}$ for $48 \mathrm{~h}$ to dry, and weighed again after drying to determine moisture content.
Vegetation characteristics within the plot were measured along the four cardinal directions and at the center of the nest. We measured percent cover of blackberry (Rubus spp.), salal, salmonberry (Rubus spectabilis), sword fern, and bracken fern (Pteridium aquilinum) using a $1 \mathrm{~m}^{2}$ quadrat at 5,10 , and $15 \mathrm{~m}$. Percent cover of bare ground, woody debris, organic cover, and other shrubs, forbs, and trees was also measured within these plots. All quadrat measurements were conducted by the same individual to prevent bias in observations between plots and sites.

We compared categorical data such as numbers of active and inactive burrows, woody debris by decay class, and number of stumps in two size classes using a $\chi^{2}$ test. Vegetation differences between the sites were determined using a nested ANOVA design (SAS model PROC MIXED). Data were assessed for heterogeneity of variances and normality and normalized by a square root or arcsine transformation (Zar 1996). We used a nonparametric Wilcoxon test on those data that could not be normalized through transformation. Data were considered significant at the $P \leq 0.05$ level.

\section{Population estimates and reinvasion}

Population estimates were based on trapping efforts and the minimum number of animals known to be alive during both livetrapping and removal trapping. At the completion of the study (June 2003), we removed animals from both study sites to determine reinvasion potential. Removal trapping sessions were conducted for 5 days, which was adequate to capture $\geq 90 \%$ of the animals (W.M. Arjo, unpublished data). Both study sites were then retrapped between October and November of 2003 to determine reinvasion. The Sylvia site was trapped an additional time in June 2004 owing to high population reinvasion in fall 2003 .

\section{Results}

\section{Trapping and monitoring}

We captured and collared 20 subadult and adult mountain beavers, 11 males and 9 females, from February 2002 through February 2003 on the Donovan site. Subadults are distinguishable only in August and September, following birth, and were therefore not used as a separate category in any analyses. Six individuals were recaptured and their collars exchanged later during the study. On the Sylvia site we captured and collared 21 individuals, 14 males and 7 females, from May 2002 through February 2003. Trapping was suspended after the first night during May 2002 during the initial trapping period on Sylvia owing to late-lactating females and the deaths of 4 females. In addition, 3 animals were recaptured and their collars exchanged.

Capture myopathy was considered the cause of death if the animal died $\leq 1$ week after capturing and handling. Mountain beavers were captured 82 times (including recaptures) and 5 animals most likely died because of capture myopathy. No juveniles were radio-collared, so survival estimates are based only on adults. Survival rates on the Donovan site were low for both males and females in 2002 but were not different between the sexes $(z=0.78, P=0.21$; Table 1). Survival rates were higher in 2003 than in 2002 but were similar between males and females $(z=-0.17, P=$ 0.43 ). Survival rates for males did not differ between 2002 
Table 1. Survival rates for adult mountain beavers (Aplodontia rufa) on the Donovan site in Grays Harbor County, Washington, 2002-2003.

\begin{tabular}{|c|c|c|c|c|c|c|c|c|}
\hline \multirow[b]{2}{*}{ Interval } & \multicolumn{4}{|l|}{ Males } & \multicolumn{4}{|l|}{ Females } \\
\hline & $\begin{array}{l}\text { No. of } \\
\text { animals }\end{array}$ & $\begin{array}{l}\text { Survival } \\
\text { rate }\end{array}$ & Variance & $95 \% \mathrm{CI}$ & $\begin{array}{l}\text { No. of } \\
\text { animals }\end{array}$ & $\begin{array}{l}\text { Survival } \\
\text { rate }\end{array}$ & Variance & $95 \% \mathrm{Cl}$ \\
\hline 2002 & 11 & 0.36 & 0.027 & $0.15-0.88$ & 8 & 0.19 & 0 & $0.044-0.81$ \\
\hline 2003 & 6 & 0.50 & 0.040 & $0.23-1.0$ & 2 & 0.54 & 0 & $0.16-1.0$ \\
\hline Reproductive season 2002 & 8 & 0.39 & 0.034 & $0.16-0.98$ & 8 & 0.37 & 0.034 & $0.14-0.98$ \\
\hline Nonreproductive season & 7 & 0.69 & 0.033 & $0.41-1.0$ & 4 & 0.72 & 0.057 & $0.37-1.0$ \\
\hline Reproductive season 2003 & 5 & 0.61 & 0.046 & $0.30-1.0$ & 2 & 0.52 & 0.116 & $0.14-1.0$ \\
\hline
\end{tabular}

Note: Seasonal survival was calculated for reproductive (1 February - 30 June) and nonreproductive (1 July - 31 January) seasons.

Table 2. Survival rates for adult mountain beavers on the Sylvia site in Grays Harbor County, Washington, $2002-2003$.

\begin{tabular}{|c|c|c|c|c|c|c|c|c|}
\hline \multirow[b]{2}{*}{ Interval } & \multicolumn{4}{|l|}{ Males } & \multicolumn{4}{|l|}{ Females } \\
\hline & $\begin{array}{l}\text { No. of } \\
\text { animals }\end{array}$ & $\begin{array}{l}\text { Survival } \\
\text { rate }\end{array}$ & Variance & $95 \% \mathrm{CI}$ & $\begin{array}{l}\text { No. of } \\
\text { animals }\end{array}$ & $\begin{array}{l}\text { Survival } \\
\text { rate }\end{array}$ & Variance & $95 \% \mathrm{Cl}$ \\
\hline 2002 & 14 & 0.57 & 0.025 & $0.32-0.99$ & 6 & 1.0 & 0 & $1.0-1.0$ \\
\hline 2003 & 7 & 0.56 & 0.031 & $0.29-1.0$ & 5 & 0.47 & 0.042 & $0.20-1.0$ \\
\hline Reproductive season 2002 & 11 & 0.54 & 0.037 & $0.27-1.0$ & 3 & 0.64 & 0.083 & $0.26-1.0$ \\
\hline Nonreproductive season & 8 & 0.64 & 0.026 & $0.40-1.0$ & 6 & 0.75 & 0.045 & $0.43-1.0$ \\
\hline Reproductive season 2003 & 5 & 0.81 & 0.027 & $0.55-1.0$ & 3 & 0.27 & 0.041 & $0.06-1.0$ \\
\hline
\end{tabular}

Note: Seasonal survival was calculated for reproductive (1 February - 30 June) and nonreproductive (1 July - 31 Jamuary) seasons.

and $2003(z=-0.41, P=0.34)$. The fate of 2 females is unknown because their signals were lost and they were never recaptured during any trapping period. Captures of other radio-collared mountain beavers documented excessive chewing on antennas that caused a failure of transmitter signals. Female survival rates also did not differ on the Donovan site between years $(z=-0.15, P=0.44)$. Predation accounted for 7 mountain beaver deaths, and 3 deaths were due to unknown causes (either the carcass was not recovered or there were no visible signs of injury or cause of death). Five mountain beavers were killed underground and their remains usually found in the nest. Characteristic killing methods (e.g., bite at the base of the skull, and only skin and skull remaining) suggested that predators were mustelids, probably mink (Mustela vison Schreber, 1777), spotted skunk (Spilogale gracilis Merriam, 1890), or long-tailed weasel (Mustela frenata Lichtenstein, 1831), which are occasionally captured in mountain beaver runways. Recovery of mountain beavers in nests confirmed our ability to locate nests from above ground for the vegetation analyses. Remains of the other two mountain beavers killed by predators were located above ground; they were killed by either a coyote (Canis latrans Say, 1823) or a bobcat (Lynx rufus (Schreber, 1777)), but not enough evidence was available to distinguish between the two predators.

Predation accounted for 8 of the 11 mountain beaver deaths on the Sylvia study site. Bobcats and raptors (unknown species) were the main predators of mountain beavers on this site. Raptors were implicated in two mountain beaver deaths when collars were found in large old-growth fir trees. Two deaths were due to unknown causes: one animal died in a large stump from which we were unable to recover the carcass, and the other carcass was not recovered before the transmitter signal was lost. Signals from three an-
Fig. 1. Mountain beaver (Aplodontia rufa) activity on two sites in western Washington.

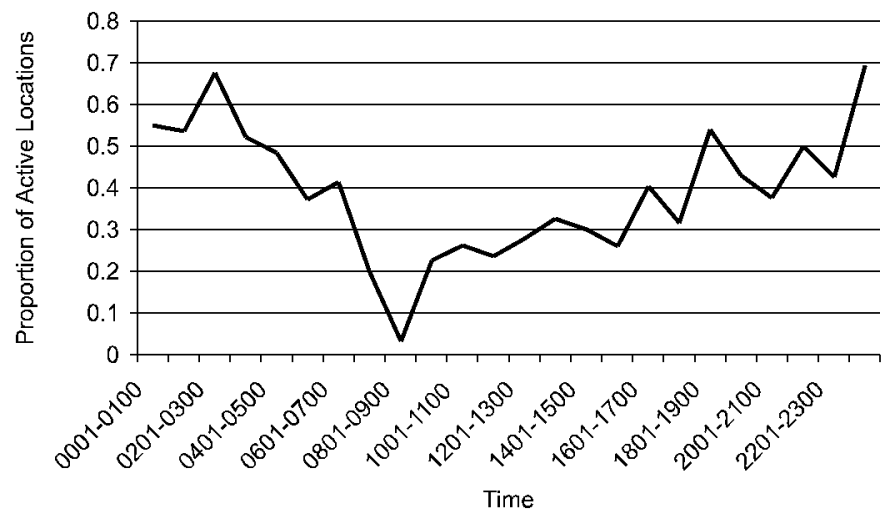

imals were lost without the transmitter ever switching to mortality mode, and these animals were never recovered or trapped during subsequent efforts. We conducted extensive multi-day searches around the site and the surrounding area to locate missing collars but were unsuccessful at recovery. Transmitter failures from destroyed antennas may have hindered recovery. Male and female survival rates were similar within years (Table 2; 2002: $z=-0.71, P=0.24 ; 2003: z=$ $1.04, P=0.15)$. Survival varied between years for females ( $z=1.64, P=0.04$ ), being lower in 2003 than in 2002, but not for males $(z=0.03, P=0.49)$.

During the last week of January and the first week of February 2003 on the Donovan site, we documented two instances of a radio-collared male and a radio-collared female together. This period is the mating season for mountain beavers, which is generally of short duration, $\leq 2$ weeks. A male and a female were located together on 24 January, yet they 
Table 3. Home ranges (ha), estimated using the adaptive kernel method $(95 \%$ and $62 \%$ for total and core use, respectively), for mountain beavers in coastal Washington on harvested forest sites with two different site-preparation regimes.

\begin{tabular}{|c|c|c|c|c|c|c|}
\hline \multirow[b]{2}{*}{ Site } & \multicolumn{3}{|l|}{ Males } & \multicolumn{3}{|c|}{ Females } \\
\hline & Mean & SE & $N$ & Mean & $\mathrm{SE}$ & $N$ \\
\hline \multicolumn{7}{|l|}{ Donovan } \\
\hline Total home range & 4.16 & 0.69 & 7 & 4.19 & 1.54 & 7 \\
\hline Total core use area & 0.73 & 0.13 & 7 & 1.02 & 0.44 & 7 \\
\hline Nonreproductive season 2002 & 2.68 & 1.32 & 7 & 2.1 & 0.77 & 5 \\
\hline Reproductive season 2003 & 1.34 & 0.47 & 5 & 1.5 & 0.16 & 3 \\
\hline \multicolumn{7}{|l|}{ Sylvia } \\
\hline Total home range & 1.26 & 0.5 & 9 & 1.7 & 0.82 & 4 \\
\hline Total core use area & 0.22 & 0.08 & 9 & 0.58 & 0.35 & 4 \\
\hline Nonreproductive season 2002 & 0.98 & 0.52 & 7 & 1.0 & 0.46 & 3 \\
\hline Reproductive season 2003 & 0.84 & 0.36 & 3 & - & - & - \\
\hline
\end{tabular}

were $>176 \mathrm{~m}$ apart the day before location and $>97 \mathrm{~m}$ apart 2 days later. We also captured a male and a female $<6 \mathrm{~m}$ apart during a trapping session on 4 February. This male was back in his own territory $\leq 1$ week later.

Reproduction varied between the study sites. Only one female on the Donovan study site was known to have produced pups in 2002 , but these did not survive to weaning following the death of the female. Numbers of juveniles on the Sylvia site ( 0.43 pups/female) are potentially biased from the early spring trapping in 2002, which caused the loss of 4 lactating females prior to pup documentation. The following spring, however, pup production averaged 0.88 pups/female.

\section{Home ranges, activity, and movements}

We obtained $>4500$ mountain beaver locations combined for both study areas. Mountain beavers were active throughout the $24 \mathrm{~h}$ period, but greater proportions of active locations were documented between 0200 and 0300,1800 and 1900, and 2200 and 2300 (Fig. 1). Mountain beavers with over 30 locations for the duration of the study and for each season were used in home range and core area calculations. Statistical analysis of home ranges $\left(F_{[3,23]}=2.79, P=0.06\right)$ and core use areas $\left(F_{[3,23]}=1.85, P=0.17\right)$ indicated that the covariate sex was not significant for either response, while site was an important effect. We found that Donovan home ranges $(P=0.009)$ and core use areas $(P=0.05)$ were larger than those observed at Sylvia (Table 3). Only two males and two females on the Donovan site survived the entire study period. Spring 2002 home ranges on the Donovan site were larger than spring home ranges at Sylvia for both sexes $\left(F_{[3,12]}=4.16, P=0.03\right)$, but no difference was observed between the sexes within a site $(P=0.26)$. We were unable to calculate spring 2003 ranges for females owing to low sample size of radio-collared females during this period. Home ranges and core areas (Fig. 2A) overlapped on the Donovan site but were usually independent on the Sylvia site (Fig. 2B).

Mountain beavers captured in summer after emergence from the nest were too small to radio collar $(<400 \mathrm{~g})$. We were, however, able to document dispersal of a few animals captured and collared in early fall. Three males were docu- mented on the Donovan site as dispersing from their original home ranges $(142.7 \pm 47.5 \mathrm{~m})$. A male from Sylvia dispersed a straight-line distance of $222 \mathrm{~m}$ in less than 1 year to establish a new territory. However, this animal made $\geq 3$ long-distance movements, first off of the Sylvia site and into the surrounding regeneration forests and then back onto the site. A female also dispersed across the site, a distance of $326 \mathrm{~m}$. Two other males dispersed shorter distances (23 and $39 \mathrm{~m}$ ) within the Sylvia site.

\section{Habitat identification}

We documented habitat characteristics for 9 Donovan and 10 Sylvia nest locations. The numbers of active and inactive mountain beaver burrows differed significantly, with Sylvia plots containing more active burrows than Donovan plots $(P<0.0001)$. A larger portion of uprooted $(P<0.001)$ and cut stumps of all sizes $(P=0.05)$ and more woody debris in all decay classes $(P<0.001)$ were found on the Sylvia site. Mountain beavers preferred moderate slopes located within the draw systems on both the Donovan site $\left(19.4^{\circ} \pm 3.11^{\circ}\right)$ and the Sylvia site $\left(20.1^{\circ} \pm 1.7^{\circ}\right)$, and no mountain beavers were located along the flat central portion of the Donovan site. Both sites contained non-friable soils (high moisture content) that maintained the structural integrity of the burrow systems. Salal $(0.04 \% \pm 0.04 \%$ and $0.88 \% \pm 0.45 \%)$ and sword fern $(16.0 \% \pm 1.97 \%$ and $16.5 \% \pm 1.59 \%)$ cover were similar on the Donovan and Sylvia sites, respectively, as were most other vegetation characteristics. The exceptions were that more blackberry covered mountain beaver nest locations on the Donovan site $(27.9 \% \pm 2.82 \%)$ than on Sylvia $(13.5 \% \pm 1.89 \%)$ and more herbaceous forbs coverage occurred on the Sylvia site $(26.0 \% \pm 1.93 \%)$ than on Donovan $(5.4 \% \pm 0.83 \%)$.

\section{Population estimates and reinvasion}

Population size in the spring of 2003 on the Donovan site ( 0.49 mountain beavers/ha) was only half of the original 2002 estimate ( 0.99 mountain beavers/ha) based on livetrapping (Table 4). Unlike the Donovan site, the population of adults at Sylvia more than doubled from 2002 (2.13 mountain beavers/ha) to 2003 (4.38 mountain beavers/ha).

During spring 2003 we removed 3 radio-collared animals 
Fig. 2. Overall core use areas (62\% adaptive kernel estimates) for mountain beavers in coastal Washington from 2002 to 2003 on (A) an herbicide-treated site (Donovan) and (B) a non-herbicide-treated site (Sylvia).

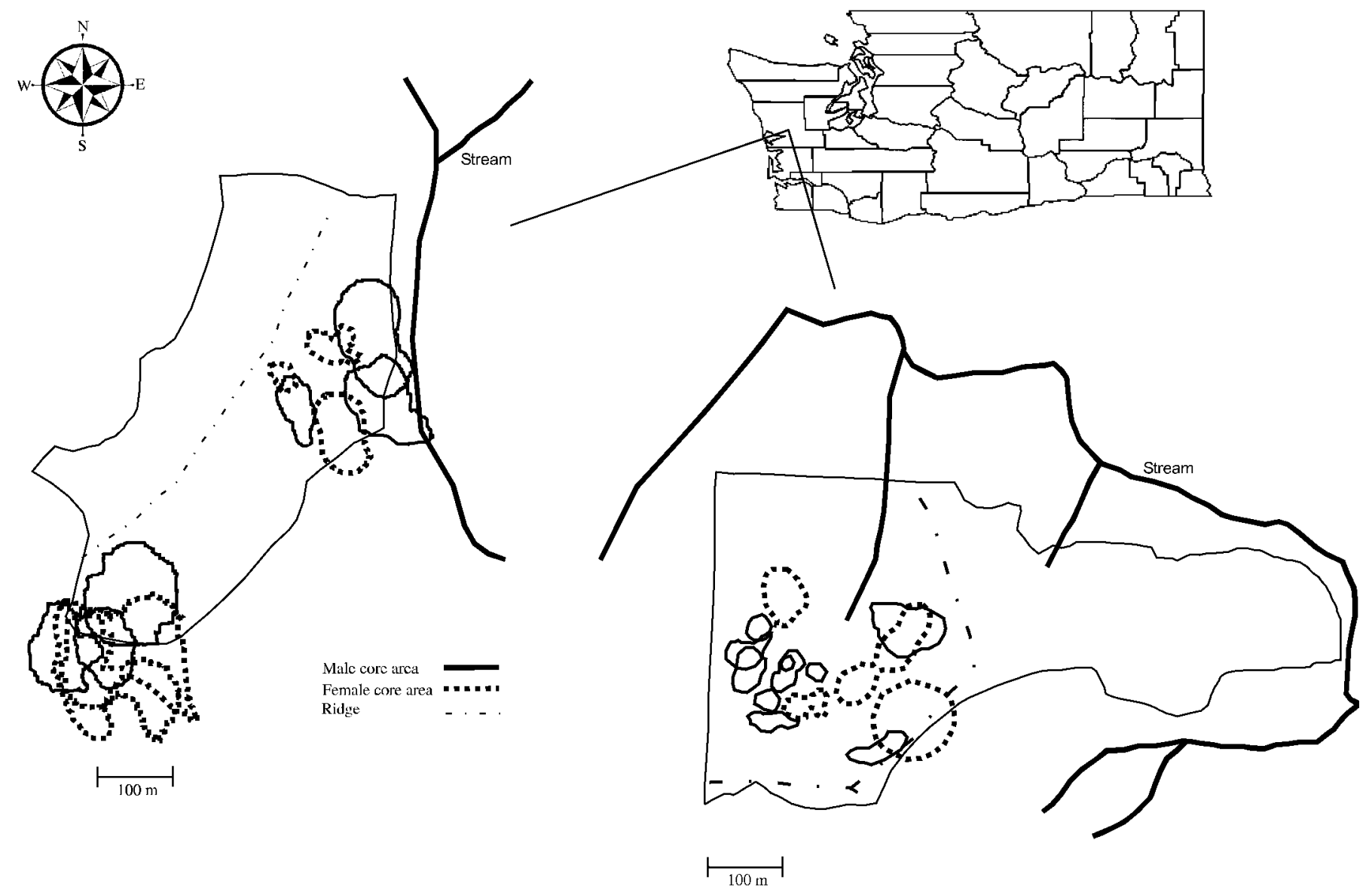

A

$\mathrm{B}$

Table 4. Population estimates (minimum number known to be alive) for mountain beavers on two recent forest harvest sites in coastal Washington.

\begin{tabular}{|c|c|c|c|c|c|c|c|c|c|}
\hline \multirow[b]{2}{*}{ Trapping period } & \multicolumn{4}{|c|}{ Donovan (16.6 ha) } & \multicolumn{5}{|c|}{ Sylvia (8.9 ha) } \\
\hline & Male & Female & Juvenile & $\begin{array}{l}\text { No. of trap } \\
\text { nights }\end{array}$ & Male & Female & Juvenile & Unknown & $\begin{array}{l}\text { No. of trap } \\
\text { nights }\end{array}$ \\
\hline Spring 2002 & 8 & 8 & 0 & 122 & 8 & 11 & 3 & - & 112 \\
\hline Fall 2002 & 6 & 4 & 0 & 192 & 6 & 6 & 0 & - & 209 \\
\hline Spring 2003 & 6 & 2 & 0 & 345 & 21 & 18 & 16 & - & 858 \\
\hline Fall 2003 & 3 & 4 & 0 & 136 & 17 & 8 & 0 & 2 & 550 \\
\hline Spring 2004 & - & - & - & - & 13 & 3 & 4 & - & 304 \\
\hline
\end{tabular}

and 5 other adults from the Donovan site (Fig. 3A). Only one collared female was not recaptured during this period, which confirmed that trapping was an effective way to estimate reinvasion, since we were able to capture $\geq 90 \%$ of the known animals. We returned to the study site 4 months later and captured an additional 7 animals, including the one remaining collared female. Reinvasion occurred at only two localized areas within the Donovan site (Fig. 3B). The spring 2003 trapping period at Sylvia yielded 6 collared and 33 uncollared individuals (Fig. 4A). An additional 25 animals were captured in fall. Owing to the large number of animals captured in fall 2003, we conducted one more re- moval trapping session in spring 2004. Sixteen additional adults and 3 juveniles were removed from the study site $\leq 8$ months after trapping (Fig. 4B).

\section{Discussion}

Mountain beaver densities are related to stand openness, and peak densities are usually reached in early to mid seral stage forests containing an undergrowth of shrubs and forbs (e.g., salmonberry, salal, blackberry, and sword fern; Scheffer 1929; Hooven 1977; Carraway and Verts 1993; Hacker and Coblentz 1993). On a young forest site $\leq 8$ years 
Fig. 3. (A) Mountain beaver captures on the Donovan site in coastal Washington. Collared animals were originally captured in 2002. All remaining radio-collared animals were removed in June 2003 in addition to uncollared individuals. (B) Mountain beaver reinvasion on the Donovan site by the fall of 2003. Animals had been removed from this site through trapping in June 2003. The Riparian Management Zone (RMZ) is a buffer area around fish-bearing streams containing $\leq 30$-year-old forested habitat.
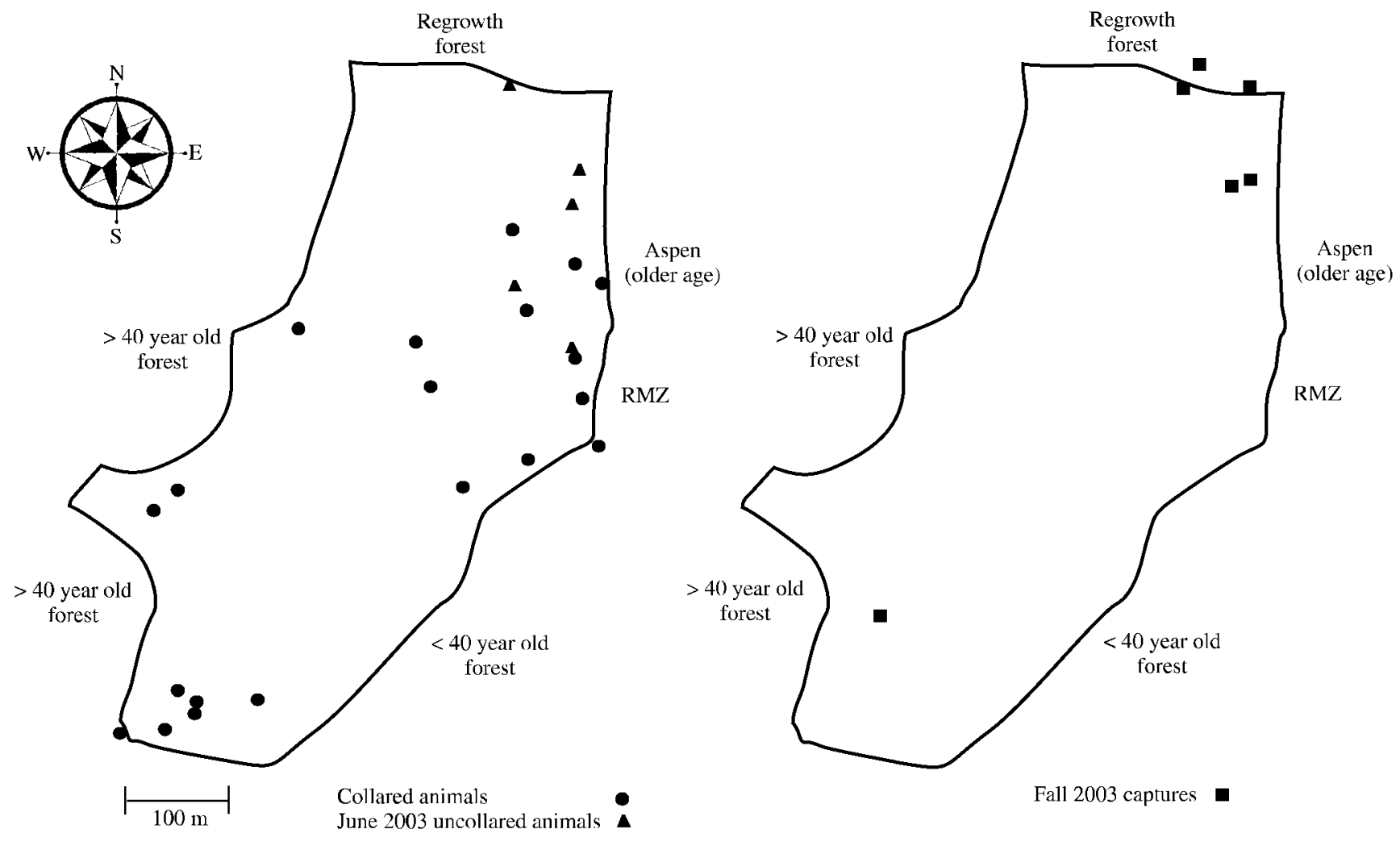

Fall 2003 captures

A

old, mountain beaver densities were estimated at 4.8 mountain beavers/ha based on effective trapping area (Lovejoy and Black 1979b). As stands mature, population densities tend to decrease, as documented on two $\geq 20$-year-old forested sites in western Washington, where populations were estimated at 3.4 and 3.6 mountain beavers/ha based on livetrapping (Neal and Borrecco 1981). Because of the mountain beaver's preference for stand openings and less dense canopy cover, recently planted clear-cuts offer an attractive habitat for dispersing mountain beavers. In 2002 we documented 0.99 mountain beavers/ha on Donovan, a recently harvested and herbicide-treated forest site, and 2.13 mountain beavers/ha (initially in spring) on Sylvia, a recently harvested but untreated site. Mountain beaver density decreased on the Donovan site the following year, after herbicide treatments became effective, but doubled on the Sylvia site. Mountain beavers are not gregarious and do not tolerate other conspecifics within their burrow system (Nolte et al. 1993) except in a brief period during the breeding season; therefore, higher densities are likely a function of suitable habitat, not social grouping (Feldhamer et al. 2003).

At Sylvia in both years, $66 \%$ of the females captured were lactating; at Donovan in 2002, 75\% of the females captured were either pregnant or lactating. Despite the higher pregnancy rates observed on the Donovan site compared with Sylvia, a low population density was observed on the
Donovan site and may be attributed to low pup survival, reduced available forbs owing to herbicide treatment, and lack of a source population around the site. Reinvasion of the Donovan site was low compared with reinvasion of the Sylvia site, which was surrounded by early seral stage habitat and a portion of the recent clear-cut. Although not quantified through trapping, the trend of increasing mountain beaver populations in younger regenerating forests has been confirmed by visual observations and data from other coastal Washington studies (Hooven 1977; Carraway and Verts 1993). Young stands offer a source population for reinvasion of newly harvested sites. Although predation accounted for a large portion of the mountain beaver deaths observed on both sites, the population on the Sylvia site doubled from 2002 to 2003 owing to continual reinvasion of the site by mountain beavers from surrounding young stands.

Mountain beaver home range estimates in a regenerating, predominately Douglas-fir forest site varied from 0.03 to 0.2 ha (Martin 1971). In late seral stage forests, home ranges were estimated at $0.26 \pm 0.04$ ha based on a rotational trapping pattern (Lovejoy and Black 1979a) and $0.17 \pm 0.02$ ha and $0.1 \pm 0.01$ ha based on telemetry data (Neal and Borrecco 1981). Mountain beaver home ranges were usually associated with stand openings that were characterized by bracken fern and forbs, species 
Fig. 4. (A) Mountain beaver captures on the Sylvia site in coastal Washington. Collared animals were originally captured in 2002. All remaining radio-collared animals were removed in June 2003 in addition to uncollared individuals. The harvested site to the east of the ridge was not trapped. (B) Mountain beaver reinvasion on the Sylvia site by the fall of 2003 . Animals had been removed from this site through trapping in June 2003. The Riparian Management Zone (RMZ) is a buffer area around fish-bearing streams containing $\leq 30$-year-old forested habitat.
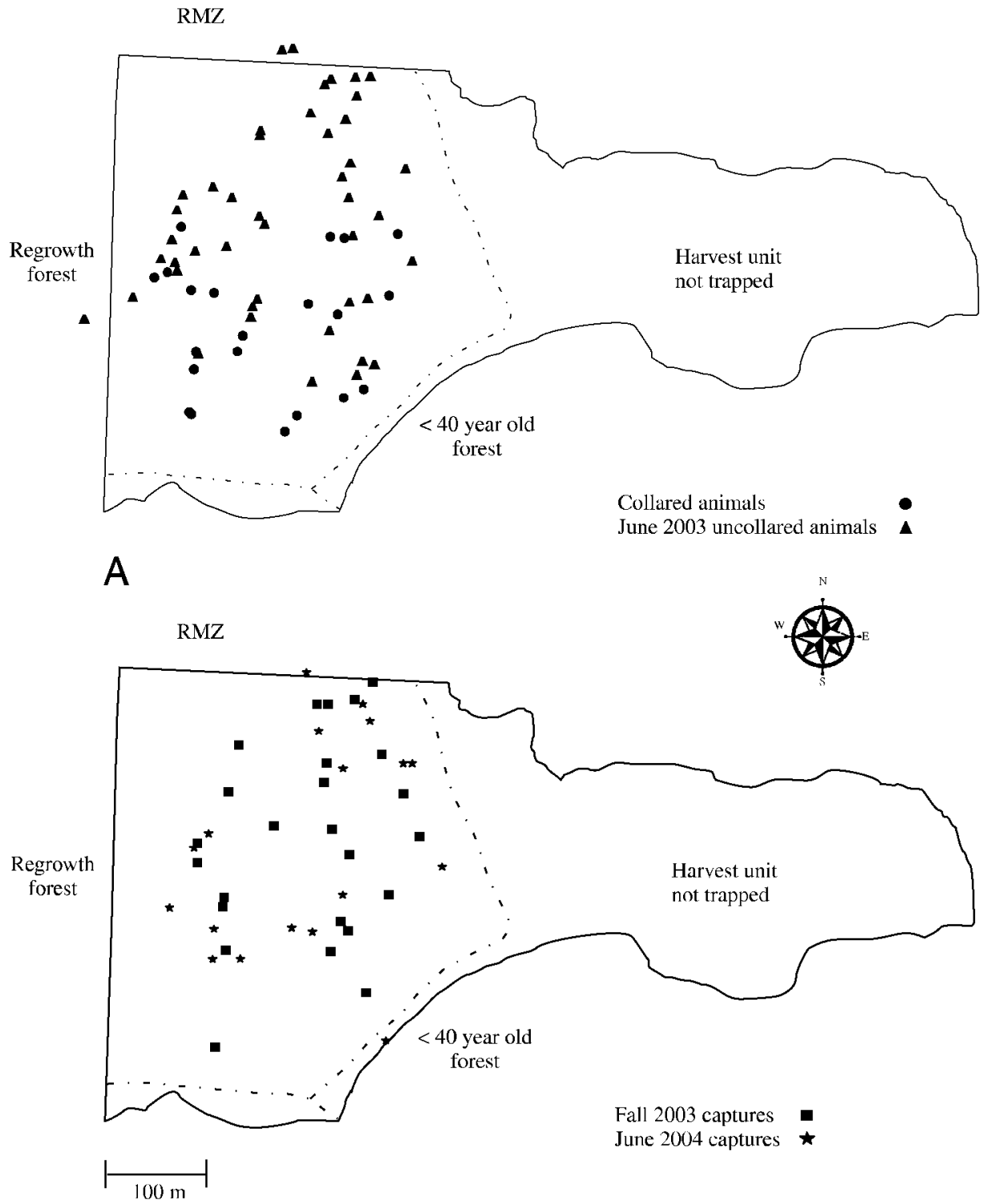

B

often found at caches during the spring and summer (Neal and Borrecco 1981). Our study estimated home ranges significantly larger than previously documented and large core areas on both study sites that often exceeded previously reported home range sizes. Additionally, home ranges and core use areas on the herbicide-treated Donovan site were twice as large as the average ranges on the untreated Sylvia site. Forage availability immediately after harvest is lower than that in regenerating stands and is reduced even further after herbicide treatment, so animals in recently harvested areas likely will have to travel longer distances to meet daily nutritional requirements.

Mountain beaver populations and movements seem to be influenced by site preparation (e.g., herbicide treatment) and available habitat. Smaller home ranges and less damage to saplings were documented on sites with greater quantities of salal and herbaceous vegetation due to the presence of more stand openings, which allowed for vegetative growth (Neal and Borrecco 1981). At least $75 \%$ of mountain beaver activity is spent gathering food (Ingles 1959), and up to 2.5 times what is eaten is clipped and stored by mountain beavers (Voth 1968). In the Pacific Northwest, clipped sword fern is often the predominant species observed at certain burrow entrances (sometimes referred to as "feeder holes" to distinguish these entrances from those that do not have nearby piles of clipped vegetation) and is thought to make up a large portion of the mountain beaver's diet (Voth 1968; Allen 1969). In this study, blackberry predominated on the 
Donovan site and no difference in sword fern availability was observed between Donovan and Sylvia. We documented lower herbaceous forb availability on the chemically prepared Donovan site. Since mountain beavers require constant water sources and succulent vegetation because of their inability to concentrate urine (Nungesser and Pfeiffer 1965; Schmidt-Nielsen and Pfeiffer 1970), vegetation at feeder holes may represent drying nest material rather than preferred forage. Sword fern is the predominant species in the majority of mountain beaver nests excavated (W.M. Arjo, personal observation). Therefore, forbs may be more important in mountain beaver diets than previously suggested and their availability may affect mountain beaver densities. Sylvia contained more available forage (e.g., forbs) for recolonizing mountain beavers and supported a larger population. This in turn may have increased social pressure, since mountain beavers are intolerant of conspecifics. Indeed, mountain beaver home ranges on the more densely populated Sylvia site were significantly smaller than those on the Donovan site, and core areas did not overlap. Smaller home ranges may also be an artifact of increased availability of forage, since animals on sites with greater forage availability would need to travel less to satisfy daily nutritional requirements. Although we found no significant difference in distance from nests to aboveground water sources between the sites, water availability may also affect home range size in a species that is highly dependent upon water. We were unable to document belowground water sources, which frequently occur in mountain beaver burrow systems. Proximity to a water source may, therefore, be underestimated when only aboveground water sources are considered.

Recolonization of sites by mountain beavers may be predominately influenced not by geographic proximity of a source population, since mountain beavers can disperse $>300 \mathrm{~m}$, but rather by habitat features such as woody cover (Hacker and Coblentz 1993). Mountain beavers frequently are located in logging slash or stumps (Martin 1971; Neal and Borrecco 1981) and use these habitat features for nest locations. Our study documented a larger population on Sylvia, which contained more woody cover to support refugia for invading and resident mountain beavers, than on Donovan. Woody areas offer more protection from excavating predators (Maser et al. 1981) as well as aerial predators. Although proximity to large source populations within regenerating forests decreased the time required for recolonization of the sites, distance did not appear to be a deterrent for recolonizing mountain beavers. We documented several long-distance forays over $200 \mathrm{~m}$ and even some longer dispersal distances $(>300 \mathrm{~m})$ that have not been previously documented in the species.

Differences we observed in mountain beaver home range size, demographics, and population density appear to be attributed to available forage (although not sword fern) and surrounding source populations and habitat. We documented larger home ranges than previously reported for mountain beavers. We speculate that this may be due to several factors, including (i) improved telemetry technology, (ii) a longer monitoring period and $24 \mathrm{~h}$ monitoring, and (iii) documentation of long-distance exploratory behavior. Mountain beavers quickly reinvaded newly created habitat, but forage availability may be limited during the first couple of years because of site disturbance and herbicide treatment, affecting both mountain beaver density and home range size. Areas occupied by mountain beavers are often easy to distinguish in the Pacific Northwest by the presence of stacked, clipped sword fern at burrow entrances; however, estimating mountain beaver populations is not easy because animals are usually solitary and defining individual burrow systems is difficult. Current mountain beaver population estimates have been limited to counts of burrows, usually active burrows determined from digging or piled vegetation (Camp 1918; Gyug 2000; Fellers et al. 2004). One of the problems associated with this method is that the number of burrows within a home range is highly variable (e.g., active burrow counts ranged from 8 to 33 burrows on Donovan and from 28 to 95 burrows on Sylvia within the 0.1-ha plots), as is the number of vegetation piles associated with an animal. In addition, dense vegetation or large debris piles may preclude monitoring in some areas and therefore bias population estimates. Sword fern monitoring can be used to show activity at burrows, but ferns may not always be taken by resident animals (Engeman et al. 1991; Zielinski and Mazurek 2006). Although both burrow and sword fern removal estimates may be biased, they are currently the only noninvasive methods available for estimating mountain beaver populations. Using the burrow estimate, we would have accurately predicted that the Sylvia site supported a larger mountain beaver population than the Donovan site.

Even though mountain beaver population densities on our study sites were not greater than densities previously reported in older stands, home ranges were larger than previously documented, and home range size appears to be affected by habitat and site preparation. Smaller home ranges occurred on the non-herbicide-treated site, where there was greater availability of forage such as herbaceous forbs and woody cover. However, this study presents information obtained from only two sites that differed in surrounding habitat, which may affect reinvasion and thus mountain beaver densities. Further testing of mountain beaver movements in different-aged stands and under varying site preparation regimes, while maintaining similar densities of surrounding vegetation, is needed to further document the effects of habitat alteration on mountain beaver populations and movements.

\section{Acknowledgements}

We thank J. Todd, the Washington Forest Protection Association, and Oregon Forest Industries Council for their support. Field efforts provided by T. Bennett, C. Bingham, J. Duvall, J. Harper, M. Jones, R. Jones, E. Meister, and R. Roberts were appreciated. We appreciate comments on the manuscript and graphical assistance provided by D. Stalman. Comments from L. Gyug and two anonymous reviewers were appreciated.

\section{References}

Allen, L.O. 1969. Preferential food habits of Aplodontia rufa. M.Sc. thesis, Central Washington State College, Ellensburg, Wash. 
Borreco, J.E., and Anderson, R.J. 1980. Mountain beaver problems in the forests of California, Oregon, and Washington. In Proceedings of the 9th Vertebrate Pest Conference, Fresno, Calif., 4-6 March 1980. Edited by J.P. Clark and R.E. Marsh. University of California, Davis, Calif. pp. 135-142.

Camp, D.L. 1918. Excavations of burrows of the rodent Aplodontia, with observations on habitat of the animals. Univ. Calif. Publ. Zool. 17: 517-536.

Carraway, L.N., and Verts, B.J. 1993. Aplodontia rufa. Mamm. Species, 431: 1-10.

Dalquest, W.W., and Scheffer, V.B. 1945. The systematic status of the races of the mountain beaver (Aplodontia rufa) in Washington. Murrelet, 26: 34-37.

Engeman, R.M., Campbell, D.L., and Evans, J. 1991. An evaluation of 2 activity indicators for use in mountain beaver burrow systems. Wildl. Soc. Bull. 19: 413-416.

Feldhamer, G.A., Rochelle, J.A., and Rushton, C.D. 2003. Mountain beaver. In Wild mammals of North America: biology, management, and economics. Edited by G.A. Feldhamer, B.C. Thompson, and J.A. Chapman. The John Hopkins University Press, Baltimore, Md. pp. 179-187.

Fellers, G.M., Pratt, D., and Griffin, J.L. 2004. Fire effects on the Point Reyes mountain beaver at Point Reyes National Seashore, California. J. Wildl. Manag. 68: 503-508.

Gaines, W.L., and Lyons, A.L. 2003. Crepuscular and nocturnal activity patterns of black bears in the North Cascades of Washington. Northwest Sci. 77: 140-146.

Gese, E.M., Rongstad, O.J., and Mytton, W.R. 1988. Relationships between coyote group size and diet in southeastern Colorado. $\mathbf{J}$. Wildl. Manag. 52: 647-653.

Government of Canada. 2007. Species at Risk Act Public Registry [online]. Government of Canada, Ottawa, Ont. Available from http://www.sararegistry.gc.ca/species/default_e.cfm [accessed 13 February 2007].

Gyug, L.W. 2000. Status, distribution, and biology of the mountain beaver, Aplodontia rufa, in Canada. Can. Field-Nat. 114: 476 490.

Hacker, A.L., and Coblentz, B.E. 1993. Habitat selection by mountain beavers recolonizing Oregon Coast Range clearcuts. J. Wildl. Manag. 57: 847-853.

Hall, E.R. 1981. The mammals of North America. 2nd ed. John Wiley, New York.

Heisey, D.M., and Fuller, T.K. 1985. Evaluation of survival and cause-specific mortality rates using radio telemetry data. J. Wildl. Manag. 49: 668-674.

Hooven, E.F. 1977. The mountain beaver in Oregon: its life history and control. Oreg. State Univ. For. Res. Lab. Res. Pap. 30.
Ingles, L.G. 1959. A quantitative study of mountain beaver activity. Am. Midl. Nat. 61: 419-423. doi:10.2307/2422511.

Lovejoy, B.P., and Black, H.C. $1979 a$. Movements and home range of the Pacific mountain beaver (Aplodontia rufa pacifica). Am. Midl. Nat. 101: 393-402. doi:10.2307/2424605.

Lovejoy, B.P., and Black, H.C. 1979b. Population analysis of the mountain beaver, Aplodontia rufa pacifica, in western Oregon. Northwest Sci. 53: 82-89.

Martin, P. 1971. Movements and activities of the mountain beaver (Aplodontia rufa). J. Mammal. 52: 717-723. doi:10.2307/ 1378920.

Maser, C., Mate, B.R., Franklin, J.F., and Dyrness, C.T. 1981. Natural history of Oregon coast mammals. U.S. For. Serv. Gen. Tech. Rep. PNW-133.

Neal, F.D., and Borrecco, J.E. 1981. Distribution and relationship of mountain beaver to openings in sapling stands. Northwest Sci. 55: 79-86.

Nolte, D.L., Epple, G., Campbell, D.L., and Russell, J.R. 1993. Response of mountain beaver (Aplodontia rufa) to conspecifics in their burrow system. Northwest Sci. 67: 251-255.

Nungesser, W.C., and Pfeiffer, E.W. 1965. Water balance and maximum concentrating capacity in the primitive rodent, Aplodontia rufa. Comp. Biochem. Physiol. 14: 289-297. PMID:14326006.

Scheffer, T.H. 1929. Mountain beavers in the Pacific Northwest: their habits, economic status, and control. Farmer's Bulletin 1958. U.S. Department of Agriculture, Washington, D.C.

Schmidt-Nielsen, B., and Pfeiffer, E.W. 1970. Urea and urinary concentrating ability in the mountain beaver, Aplodontia rufa. Am. J. Physiol. 2: 1370-1375.

Shivik, J.A., Jaegar, M.M., and Barrett, R.H. 1996. Coyote movement in relation to the spatial distribution of sheep. J. Wildl. Manag. 60: 422-430.

Voth, E. 1968. Food habits of the Pacific mountain beaver, Aplodontia rufa pacifica. Ph.D. thesis, Oregon State University, Corvallis, Oreg.

White, G.C., and Garrott, R.A. 1990. Analysis of wildlife radiotracking data. Academy Press, San Diego, Calif.

Zar, J.H. 1996. Biostatistical analysis. Prentice Hall Inc., Upper Saddle River, N.J.

Zielinski, W.J., and Mazurek, M.J. 2006. The reproductive ecology and home range of the Point Arena mountain beaver (Aplodontia rufa nigra). Final Report to the USFWS, USDA Forest Service, Pacific Southwest Research Station, Arcata, Calif. 